\title{
The Physiochemical Condition of Mangrove Ecosystems in The Coastal District of Sulamo, Kupang, East Nusa Tenggara, Indonesia
}

\author{
Erny Poedjirahajoe ${ }^{1 *}$, Jeriels Matatula ${ }^{2}$
}

\author{
${ }^{1}$ Department of Forest Resources Conservation, Forestry Faculty, Universitas Gadjah Mada. Jl. Agro No.1 Bulaksumur, \\ Sleman, Yogyakarta, Indonesia 55281 \\ ${ }^{2}$ Forestry Field Program, Politeknik Pertanian Negeri Kupang. J1. Prof. Herman Johanes, Lasiana, \\ Kupang, Indonesia 85011
}

Received September 16, 2019/Accepted November 19, 2019

\begin{abstract}
Various rehabilitation and restoration of mangrove forests have been done, but there have not been any significant results. The main reason for the various failures in this activity is that the effort is not based on scientific data such as the suitability of the physicochemical conditions of mangrove habitats along the beach coast of Sulamo District. The purpose of this research is to analyze the condition of salinity, the thickness of mud, and the beach slope of the selected mangrove locations Oeteta, Pariti, Beringin, and Pitai beaches. The salinity conditions show variations, ranging from 19 ppm to 42.33 ppm. The thickness of the mud shows the highest value at $79.11 \mathrm{~cm}$ and the slope of mangrove coastal 1-4\%. This research shows that the condition of the mangrove ecosystem in the coastal district of Sulamo is still suitable for mangrove growth. This research provides a basic overview of mangrove ecosystem conditions located on the beach coast of the Sulamo district as the basis for planning rehabilitation programs and mangrove restorations in the research area.
\end{abstract}

Keywords: beach slope level, mangrove habitat, mangroveforest, mud thickness, salinity level

*Corresponding author, email: poedjirahajoe19@gmail.com

\section{Introduction}

Mangrove ecosystem is known to play an important role in the coastal environment, biology, and environmental health (Baran, 1999). Mangrove is the coastal ecosystem that provides the highest bioligatic productivity (Alonggi, 2002). The mangrove ecosystem has ecological functions in absorbing carbon, pollutant remediation, abrasion prevention, intrusion, and storm prevention (Wiryanto et al., 2017), while also able to function as a habitat for growth and development of aquatic fauna (Matatula et al., 2019). Mangrove is a habitat of various types of microorganisms that are tolerant of extreme environmental conditions (Retnowati et al., 2017), mangrove also provides a crucial role to preserve biodiversity (Husodo et al., 2017). The mangrove ecosystem provides protection services for the small fish, fish larva and shells from predatory attacks (Lapolo et al., 2018), this causes mangrove forests to play a significant role in coastal ecosystems including ecological, social, and economic aspects (Basyuni et al., 2018; Schaduw, 2018). The mangrove ecosystem can increase fishery products by up to $23 \%$ of the normal value (Anneboina \& Kumar, 2012). The mangrove ecosystem showed degradation due to population growth and excessive human activities (Matatula et al., 2018). Various building activities such as reclamation, physical development along the coastline, and pollution are the cause of degradation and the intrusion of the mangrove forest ecosystem (Husodo et al., 2017). The conversion of mangrove forests to pond is one of the most significant contributors to the destruction of mangrove forests (Kunarso et al., 2015). Therefore, the sustainable management of mangroves should be done by all government institutions (Febryano et al., 2014), by applying the appropriate social models in the management of mangroves (Sulistyorini et al., 2018).

The quality of the mangrove ecosystem is very affecting the health condition of mangrove plants, although this plant is famous for plants that have a high adaptation to the change in environmental conditions (Matatula et al., 2017). Physiochemical conditions such as salinity, mud thickness, and coastal slope are the parts of the environment factor affecting the existence of mangrove ecosystems in a place (Matatula et al., 2019). The Sulamo Subdistrict has mangrove forests that are located along the coast, where the mangrove forest is experiencing various pressures such as conversion into fish ponds and salt ponds. Various 
rehabilitation and mangrove restoration efforts have been carried out, but there have been no significant results. The main reason for various failures in this activity is that these efforts are not based on scientific data or without scientific studies conducted regarding the suitability of the physicochemical conditions of mangrove habitats located along the coast District of Sulamo. The purpose of this research is to analyze the conditions of salinity, the thickness of mud, and the slope of mangrove locations in the coastal District of Sulamo.

\section{Methods}

This research was conducted on the ecosystem of mangrove forests in Sulamo Subdistrict (the mangrove forests of Oeteta, Pariti, Beringin Beach, and Pitai). The research location is shown in Figure 1. This research was conducted on four locations with systematic sampling methods that were systematically distributed in mangrove forests. Measurement of environmental parameters such as salinity, mud thickness, and beach slope were carried out by using the Transect Line method and Example Plot (Transect Line Plot).

Physicochemical analysis Salinity is measured on each tile that is placed perpendicular to the coastline. At each of the research sites, pathways that penetrate the proximal zone, the medial zone, and the distal zone were created. Measuring plots (PU) were made in $10 \mathrm{~m} \times 10 \mathrm{~m}$, so the entire observation plots were $825(275 \times 3)$ tiles of 275 lanes with a distance between the lines was 50 meters (Senoaji et al. 2016). Measurement of salinity was performed by using defrakto meter. The thickness measurement of mud was done by using a 2 -meter-scale stick, while tilt measurement was carried by using clinometer. Map creation of environmental conditions was drawn by using salinity measurement data, mud thickness, and tilt measurement data. The results of the measurement of these three environmental factors were made in to (1) G-1 (for low salinity, worth 1020\%o), (2) G-2 (for moderate salinity, valued at $21-30 \%$ ), and (3) G-3 (for the high salinity, it is worth $>30 \%$ ). Class mud thickness divided into L-1: for the thickness of mud between 10-30 $\mathrm{cm}, \mathrm{L}-2$ : for the thickness of the mud $31-40 \mathrm{~cm}$, and L-3: for the thickness of the mud $>40 \mathrm{~cm}$, and for the classes of S-1: for low tilt (almost flat, worth $\leq 1.5 \%$ ), $\mathrm{S}-2$ : for medium slope (almost flat to ramps, is worth 1.6-3.0\%), and S-3: for high tilt (ramps to tilt, worth $\geq 3.0 \%$ ) (Poedjirahajoe, 2006).

Cluster analysis was used to analyze the combined status of the mangrove habitat conditions. Cluster analysis will indicate the pattern of grouping of habitat conditions, the level of similarity, or variations with regard to the studied physicochemical parameters between the different research locations located on the same stretch of beach. This analysis is based on calculating the mean Euclidean distance, as proposed by Ludwig and Reynold (1988). The formula used was as follows as Equation [1]:

$d_{i j}=\sqrt{\frac{\sum_{k=1}^{m}\left(x_{i k}-x_{j k}\right)^{2}}{m}}$

note: $D_{i j}=$ matrix data distance coefficient level $i$ to level $j ; X_{i k}$ $=$ parameters measured in level (experimental unit) $\mathrm{i} ; \mathrm{X}_{\mathrm{jk}}=$ parameters measured in level (experimental unit); $\mathrm{j}, \mathrm{m}=$ total parameters measured.

\section{Results and Discussion}

Condition of salinity mangrove ecosystem The increase of population indirectly gives the determination of the mangrove ecosystem (Matatula, 2010). This happens because of various development oriented to the aspect of economics or its negatively impacts the mangrove forest ecosystem. Dahuri (2003) said that development activities focused on coastal areas impact environmental sustainability and the existence of the mangrove ecosystem. One of the environmental factors that are very influential for the mangrove ecosystem is salinity. Salinity strongly affects the growth of mangrove forests and the survival of biota in the mangrove ecosystem. The condition of salinity gives a maximum effect on Scylla serrata in connection with the process of osmoregulation of his body (Hastuti et al., 2015).

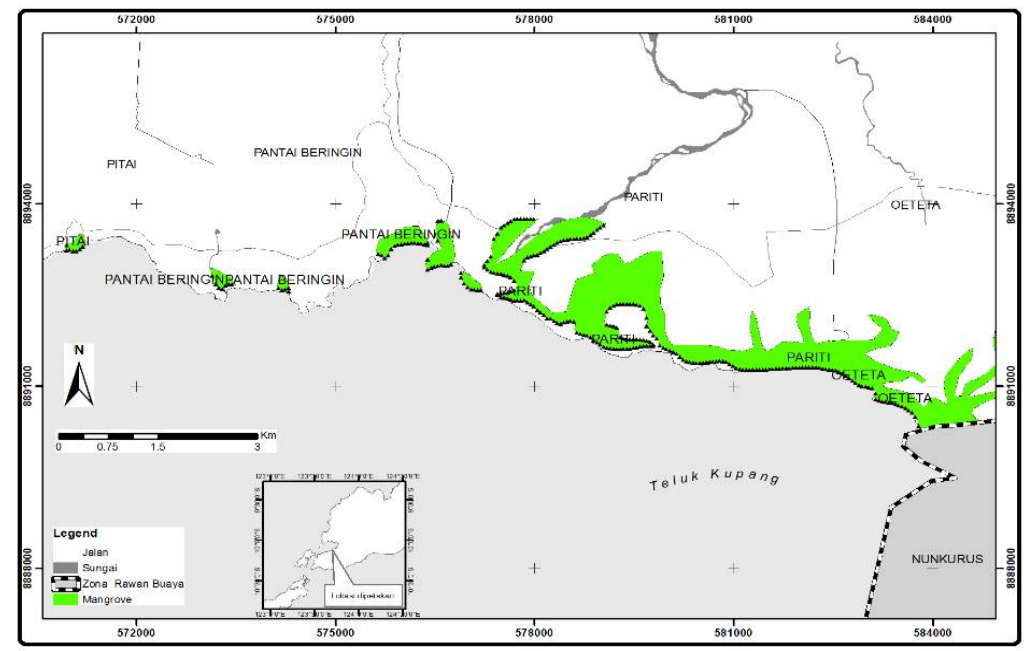

Figure 1 Map showing the mangrove research locations along the coastal area of Sulamo Subdistrict, East Nusa Tenggara, Indonesia. 
Based on the results of the measurement of salinity value at the research site in Sulamo Subdistrict (Oeteta, Pariti, Beringin Beach, and Pitai) show different diversity. This diversity of salinity occurs due to evaporation, freshwater supply, mixing of sea water, location and size of the sea, humidity, and mineral content. The salinity of the measurement results on the coastal mangrove ecosystem of Sulamo Subdistrict is shown in Table 1, Table 2, Table 3, and Table 3 .

The mangrove ecosystem on the coast of Oeteta shows the lowest salinity value of $20 \mathrm{ppm}$ and the highest value of $34 \mathrm{ppm}$ value, with the dominant salinity of $30 \mathrm{ppm}$ and 11 values of salinity diversity (Figure 2 ). The salinity range shows that the mangrove ecosystem of Oeteta supports mangrove growth, as indicated by Saparinto (2007) that the mangrove can flourish in the area Estuarine with 10-30 ppm salinity. The characteristic salinity of the mangrove forest ecosystem of Oeteta is strongly influenced by rivers flowing adjacent to the mangrove forest of Oeteta. Environmental conditions should get serious consideration. The mangrove ecosystem of Oeteta and Pariti has suffered from land degradation due to fish pond activities and salt ponds. This is in line with the opinion of Husodo et al. (2017), which states that the mangrove ecosystem is a coastal ecosystem that is currently raising damage continuously in terms of extents and quality. Poedjirahajoe (2011) also stated that environmental factors strongly affect the composition of the mangrove ecosystem, even changes in the quality of the environment complex can result in the shifting type of vegetation constituent.

Characteristic salinity of the coastal area mangrove ecosystem Pariti shows the lowest value of $19 \mathrm{ppm}$ and the highest at a value of $42.33 \mathrm{ppm}$ with the dominant value of salinity $30 \mathrm{ppm}$ and 28 diversity of salinity value (Figure 3 ). Salinity value in Pariti area is found low because some places in Pariti mangrove forest come into contact with rice fields located at the back of the mangrove forest. However, as a condition of salinity of the mangrove forest Pariti show high value of this matter because the north here is no river flowing so that there is no mixing between seawater and freshwater. The salinity character of the Sulamo Subdistrict compared to that of the mangrove ecosystem located in Oeteta and Pariti has similarities, where both regions have the same dominant salinity value. The salinity of the mangrove ecosystem at Beringin Beach shows a value of 20-32 ppm with a diversity value of 18 , and the dominant salinity value is at $20.33 \mathrm{ppm}$ (Figure 4). The decline in the salinity value that occurs in Beringin Beach is caused by the rear and the side of the mangrove ecosystem surrounded by the fish pond. The salinity of the Pariti mangrove ecosystem and the mangrove ecosystem of Beringin Beach are influenced by freshwater compounding from rice fields and fish ponds not because the river flows as in the mangrove ecosystem of Oeteta. Unlike the mangrove ecosystem of Oeteta, Pariti and Beringin Beach characteristic salinity that resides in the Mangrove Pitai ecosystem shows 30.33-40 ppm, with the dominant salinity value of $30.33 \mathrm{ppm}$, and the diversity of salinity as much as 2 (Figure 5). Condition of salinity of mangrove ecosystem in Sulamo Subdistrict if we compare with the mangrove Ecosystem in Karang Gading Wildlife Sanctuary Lankat, northeast of North Sumatera, then the value of salinity located in the mangrove ecosystem Sulamo District has value salinity that is higher considering that the Sumateran area of the drainage value is $16.21-23.53 \mathrm{ppm}$ (Siahaan, 2016). This is because in the District of Sulamo is very low the estuary of rivers flowing so that there is no mixture of freshwater and seawater. Based on the fact that the salinity of the mangrove ecosystem in Sulamo Subdistrict proves that mangrove can grow and self-fit in existing environmental conditions, it is in line with Purnobasuki et al. (2016), stating that mangrove can be used to build the stabilization of coastal ecosystems because mangrove is able to live on high salinity and resistant to large waves.

Condition of mud thickness mangrove ecosystem The mangrove forest ecosystem is a type of ecosystem located in the coastal area and regularly flooded with seawater or influenced by the tide of seawater, with muddy soil

Table 1 Salinity, mud thickness, and slope values at different sampling lines of Oeteta mangrove location, Sulamo Subdistrict, Kupang District, East Nusa Tenggara Timur, Indonesia

\begin{tabular}{lccccc}
\hline $\begin{array}{c}\text { Salinity } \\
(\mathrm{ppm})\end{array}$ & $\begin{array}{c}\text { Thickness of } \\
\text { mud }(\mathrm{cm})\end{array}$ & $\begin{array}{c}\text { Slope } \\
(\%)\end{array}$ & $\begin{array}{c}\text { Salinity } \\
(\mathrm{ppm})\end{array}$ & $\begin{array}{c}\text { Thickness } \\
\text { of mud } \\
(\mathrm{cm})\end{array}$ & $\begin{array}{c}\text { Slope } \\
(\%)\end{array}$ \\
\hline 23.66 & 29.11 & 2 & 24 & 54.88 & 2 \\
30 & 14.66 & 2 & 20.66 & 32.33 & 2 \\
30 & 14.11 & 2 & 20 & 38.66 & 2 \\
20.33 & 13.33 & 2 & 20 & 33.66 & 2 \\
23.66 & 18.44 & 1.33 & 30 & 29.55 & 2 \\
20.33 & 32.77 & 1.66 & 23.33 & 27.88 & 2 \\
23 & 38.33 & 1 & 23.33 & 17.44 & 2 \\
20 & 38.33 & 1 & 34.33 & 15.77 & 2 \\
30 & 23.88 & 1.33 & 30.66 & 13.55 & 2 \\
30 & 23.88 & 1 & 24 & 17.66 & 1.66 \\
21 & 23.22 & 1.33 & 20 & 22 & 1.66 \\
20.33 & 53.22 & 1 & 23 & 30 & 1.33 \\
20.33 & 47.22 & 1.66 & 21 & 30 & 1.66 \\
\hline
\end{tabular}


Table 2 Salinity, mud thickness, and slope values at different sampling lines of Pariti mangrove location, Sulamo Subdistrict, Kupang District, East Nusa Tenggara Timur, Indonesia

\begin{tabular}{|c|c|c|c|c|c|c|c|c|c|c|c|}
\hline $\begin{array}{l}\text { Salinity } \\
\text { (ppm) }\end{array}$ & $\begin{array}{c}\text { Thickness } \\
\text { of mud } \\
(\mathrm{cm})\end{array}$ & $\begin{array}{c}\text { Slope } \\
(\%)\end{array}$ & $\begin{array}{l}\text { Salinity } \\
\text { (ppm) }\end{array}$ & $\begin{array}{c}\text { Thickness } \\
\text { of mud } \\
(\mathrm{cm})\end{array}$ & $\begin{array}{c}\text { Slope } \\
(\%)\end{array}$ & $\begin{array}{l}\text { Salinity } \\
\text { (ppm) }\end{array}$ & $\begin{array}{l}\text { Thickness } \\
\text { of mud } \\
(\mathrm{cm})\end{array}$ & $\begin{array}{c}\text { Slope } \\
(\%)\end{array}$ & $\begin{array}{c}\text { Salinity } \\
(\mathrm{ppm})\end{array}$ & $\begin{array}{c}\text { Thickness } \\
\text { of mud } \\
(\mathrm{cm})\end{array}$ & $\begin{array}{c}\text { Slope } \\
(\%)\end{array}$ \\
\hline 21.66 & 31.55 & 2 & 19.33 & 55.55 & 3 & 35 & 43.22 & 3 & 34.66 & 43.22 & 2.66 \\
\hline 26.66 & 39.88 & 2 & 19 & 55.88 & 3 & 35 & 44.88 & 3 & 34.66 & 47.66 & 2.66 \\
\hline 25 & 39.88 & 2 & 20 & 50.11 & 2 & 35 & 43.11 & 2.66 & 35 & 44.55 & 3 \\
\hline 21.66 & 32.55 & 2 & 20 & 43.77 & 2 & 35 & 43.88 & 2.66 & 35 & 43 & 2.66 \\
\hline 27 & 33.66 & 2 & 20 & 48.77 & 2 & 34 & 47.55 & 3 & 35 & 45.55 & 2 \\
\hline 25.33 & 33.66 & 2 & 19 & 47.22 & 2 & 34 & 43.22 & 2.66 & 35 & 41.66 & 2 \\
\hline 31.66 & 39.11 & 2 & 20 & 46.44 & 2 & 34 & 45.66 & 2.66 & 35 & 46.77 & 2 \\
\hline 31.66 & 32.11 & 2 & 20 & 30.33 & 4 & 34.33 & 41 & 2.66 & 35 & 48.66 & 2 \\
\hline 31.66 & 38 & 3 & 20 & 30 & 4 & 34.33 & 47.22 & 2 & 34.33 & 43.55 & 2 \\
\hline 32.33 & 38 & 3 & 19 & 29.66 & 4 & 34.33 & 45.88 & 2 & 34.33 & 47.33 & 2 \\
\hline 39.66 & 39.88 & 3 & 20 & 30 & 4 & 34.33 & 43.44 & 2 & 34.33 & 44.55 & 2.33 \\
\hline 41.33 & 39.11 & 3 & 20 & 29 & 4 & 34 & 42 & 2 & 34 & 45 & 2.33 \\
\hline 42.33 & 32.11 & 3 & 25 & 30 & 3 & 34 & 43.11 & 2 & 34 & 42.11 & 2.33 \\
\hline 36 & 29.77 & 2 & 20 & 30.33 & 2 & 34.33 & 43.22 & 2 & 34 & 45 & 2.33 \\
\hline 36 & 23.44 & 3 & 25 & 28 & 2 & 34.33 & 42.44 & 2 & 34 & 46.66 & 2.33 \\
\hline 40 & 29.77 & 3 & 30 & 28 & 2 & 34.33 & 42 & 2 & 34 & 46 & 2.33 \\
\hline 25 & 29.77 & 2 & 30 & 26 & 2 & 34.33 & 47.55 & 2 & 34 & 46 & 2.33 \\
\hline 25 & 29.77 & 2 & 30 & 24.33 & 2 & 34.33 & 42.11 & 2 & 35 & 44.55 & 2.33 \\
\hline 23 & 29.88 & 2 & 30 & 27.66 & 2 & 34.33 & 43 & 2 & 35 & 41.55 & 2.33 \\
\hline 25 & 23.44 & 2 & 30 & 54.66 & 1 & 34.33 & 44.66 & 2 & 35 & 45.11 & 2 \\
\hline 24.33 & 29.77 & 2 & 30 & 56.33 & 1 & 34.33 & 44.66 & 2 & 35 & 46.22 & 2 \\
\hline 24 & 54.44 & 2 & 30 & 54.66 & 1 & 34.33 & 46.22 & 2 & 35 & 44.44 & 2 \\
\hline 25 & 71.11 & 2 & 30 & 70.66 & 1 & 34.33 & 44.66 & 3 & 35 & 44.66 & 2 \\
\hline 26.33 & 69.88 & 2 & 30 & 44.33 & 1 & 34.33 & 45.44 & 3 & 35 & 44.77 & 2 \\
\hline 24.33 & 63.11 & 2 & 30 & 54.66 & 1 & 34.33 & 47.88 & 3 & 34 & 44.77 & 2 \\
\hline 24.66 & 77.11 & 2 & 30 & 40.33 & 1 & 34.33 & 42.44 & 3 & 35 & 44.44 & 1.33 \\
\hline 25 & 72.11 & 2 & 35 & 39 & 3 & 34.33 & 42.22 & 2.66 & 35 & 44 & 1.33 \\
\hline 25 & 53.11 & 2 & 35 & 38 & 4 & 34 & 43.44 & 2.66 & 35 & 42.22 & 1.33 \\
\hline 25 & 54.66 & 2 & 35 & 39 & 4 & 35 & 44.55 & 2.66 & 35 & 43.44 & 1.33 \\
\hline 25 & 38.66 & 2.33 & 35 & 39.33 & 4 & 34.66 & 42.66 & 2.66 & 34 & 43.88 & 1.66 \\
\hline 25 & 56 & 2.33 & 35 & 24 & 4 & 34.66 & 42.55 & 2.66 & 34 & 43.22 & 1.66 \\
\hline 26 & 41.55 & 2.33 & 35 & 29 & 4 & 34.66 & 45.55 & 2.66 & 34 & 43.88 & 1.66 \\
\hline 24.33 & 66.88 & 2.33 & 30 & 18.33 & 1 & 35 & 41.66 & 2.66 & 34 & 42.33 & 1 \\
\hline 24.33 & 40.66 & 2.33 & 30 & 17.33 & 1 & 35 & 44.22 & 2.66 & 34 & 46.22 & 1.33 \\
\hline 24.33 & 58 & 2.33 & 30 & 24 & 1 & 35 & 41.11 & 3 & 34 & 44.88 & 1.33 \\
\hline 24 & 71.77 & 2.33 & 30 & 18.66 & 1 & 35 & 42.66 & 3 & 34 & 42.33 & 1.33 \\
\hline 24 & 42.88 & 2.33 & 30 & 37.66 & 1 & 35 & 42.66 & 3 & 34 & 47 & 1.33 \\
\hline 24 & 62.66 & 2.66 & 27.66 & 79.11 & 2 & 35 & 41.55 & 3 & 34 & 44.77 & 1.33 \\
\hline 24 & 51.55 & 2.66 & 27.66 & 74.66 & 2 & 40 & 43.88 & 3 & 34 & 48.33 & 1 \\
\hline 24.33 & 44.88 & 2.66 & 30 & 67.55 & 2 & 40 & 44.11 & 3 & 35 & 49 & 1 \\
\hline 24.33 & 53.55 & 3 & 35 & 69.11 & 2 & 34 & 45.88 & 3 & 35 & 46.33 & 1 \\
\hline 24 & 46.33 & 2.66 & 40 & 57.77 & 1 & 34 & 44.44 & 3 & 35 & 47.44 & 1 \\
\hline 24.66 & 56.77 & 2.66 & 40 & 33.66 & 1 & 34 & 45.11 & 2.66 & 34.66 & 48.11 & 1 \\
\hline 24.66 & 53.77 & 2.66 & 40 & 33.88 & 1 & 34 & 43.44 & 2.66 & 35 & 40.55 & 1 \\
\hline 24.33 & 47.11 & 2.66 & 40 & 35.66 & 1 & 34 & 44.11 & 2.66 & 35 & 45.11 & 1 \\
\hline 24.33 & 48 & 3 & 34.66 & 36.33 & 1 & 34 & 44.11 & 2.66 & 35 & 45.22 & 1 \\
\hline 24.33 & 53.55 & 3 & 35 & 42 & 3 & 34 & 46.11 & 2.66 & 34.66 & 46.77 & 1 \\
\hline 19.66 & 54.77 & 3 & 35 & 42 & 3 & 34 & 44.66 & 2.66 & 34.66 & 47 & 1 \\
\hline 19 & 55.55 & 3 & 35 & 67.55 & 3 & 34 & 46.77 & 2.66 & 34.33 & 47.44 & 1.33 \\
\hline 19.66 & 53.44 & 3 & 34.33 & 42.11 & 2.33 & 34.33 & 43.77 & 2.66 & 34 & 43.33 & 1 \\
\hline 19.33 & 50.11 & 3 & 34.66 & 43.44 & 2 & 34.66 & 45.66 & 3 & 34 & 49.88 & 1 \\
\hline 19 & 53.77 & 3 & 35 & 44.33 & 2.66 & 34.66 & 45.11 & 3 & 34 & 48.55 & 1 \\
\hline 19 & 53.77 & 3 & 35 & 47.22 & 2.66 & 34.66 & 45.22 & 2.66 & - & - & - \\
\hline
\end{tabular}


Table 3 Salinity, mud thickness, and slope values at different sampling lines of Pantai Beringin mangrove location, Sulamo Subdistrict, Kupang District, East Nusa Tenggara Timur, Indonesia

\begin{tabular}{llllcc}
\hline $\begin{array}{c}\text { Salinity } \\
(\mathrm{ppm})\end{array}$ & $\begin{array}{c}\text { Thickness of } \\
\text { mud }(\mathrm{cm})\end{array}$ & $\begin{array}{c}\text { Slope } \\
(\%)\end{array}$ & $\begin{array}{c}\text { Salinity } \\
(\mathrm{ppm})\end{array}$ & $\begin{array}{c}\text { Thickness of } \\
\text { mud }(\mathrm{cm})\end{array}$ & $\begin{array}{c}\text { Slope } \\
(\%)\end{array}$ \\
\hline 20.66 & 56.55 & 3 & 26.66 & 37.66 & 1 \\
20.66 & 58.77 & 3 & 20.66 & 38.66 & 1.66 \\
21.66 & 56.55 & 2.33 & 20.33 & 40 & 2.33 \\
27.33 & 47.55 & 2 & 22 & 37.66 & 2 \\
27.33 & 28.55 & 2 & 27.66 & 48.66 & 2 \\
25 & 20.33 & 2 & 30 & 50 & 2 \\
20.33 & 26.88 & 2 & 28.33 & 48 & 2 \\
24 & 22.77 & 3 & 23.66 & 53 & 2 \\
20.33 & 27.33 & 3 & 24 & 50 & 2 \\
24 & 23.55 & 2 & 20 & 27.55 & 2 \\
26 & 20.33 & 1 & 30 & 19.55 & 2 \\
30 & 28.55 & 1.33 & 31 & 19.55 & 2 \\
31 & 27.33 & 1 & 30.66 & 19.55 & 2 \\
26.66 & 24.55 & 1 & 31 & 20.44 & 2 \\
25.33 & 35.55 & 1 & 32 & 25.11 & - \\
20.33 & 40 & 1 & - & - & \\
\hline
\end{tabular}

Tabel 4 Salinity, mud thickness, and slope values at different sampling lines of Pitai mangrove location, Sulamo Subdistrict, Kupang District, East Nusa Tenggara, Indonesia

\begin{tabular}{lll}
\hline $\begin{array}{c}\text { Salinity } \\
(\mathrm{ppm})\end{array}$ & $\begin{array}{c}\text { Thickness of mud } \\
(\mathrm{cm})\end{array}$ & $\begin{array}{c}\text { Slope } \\
(\%)\end{array}$ \\
\hline 32.33 & 29.88 & 2.33 \\
40 & 26.55 & 2.66 \\
33 & 30.88 & 3 \\
38.33 & 37.88 & 2 \\
30.33 & 35.55 & 3 \\
33.33 & 37.66 & 2 \\
30.33 & 31.55 & 2 \\
\hline
\end{tabular}

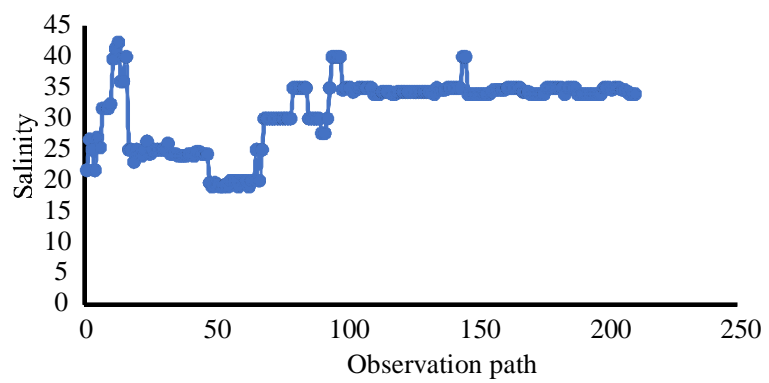

Figure 3 Variation in salinity along sampling lines of Pariti mangrove location.

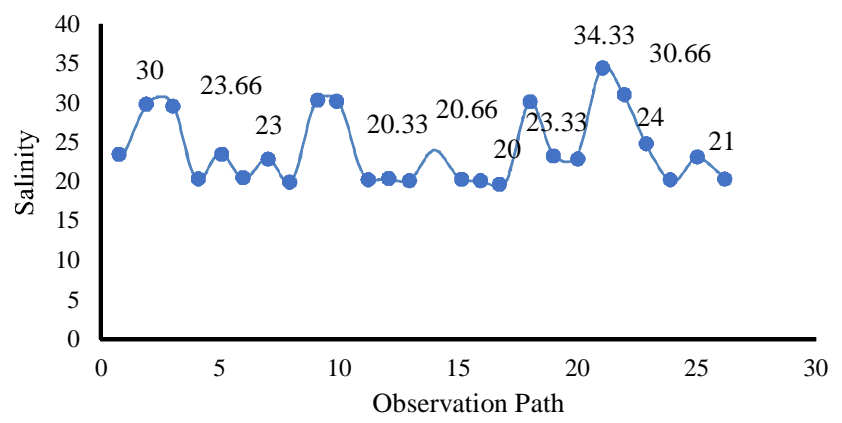

Figure 2 Variation in salinity along sampling lines of Oeteta mangrove location.

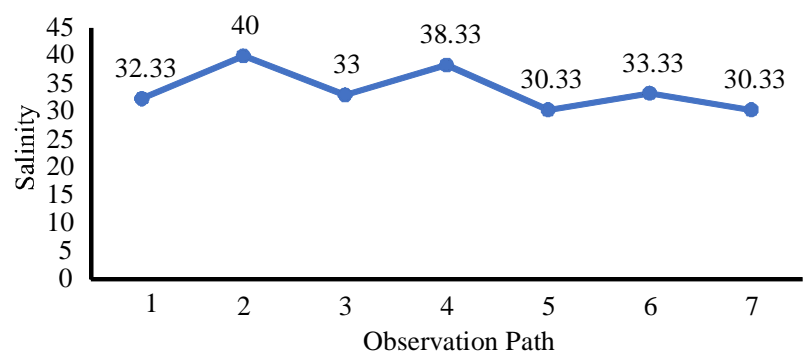

Figure 4 Variation in salinity along sampling lines of Pitai mangrove location. 
conditions, sandy, or sandy mud. At the site of the mangrove forest ecosystem research located in the District of Sulamo shows different characteristics and diversity. The thickness of the mud is an environmental factor affecting the growth of vegetation and survival in the mangrove ecosystem. The uniqueness of mangrove forest can be seen in the habitat condition of his life, also the biodiversity flora that is capable of survival (Davinsy et al., 2015).

Conditions of the thickness of mud ecosystem of the mangrove Oeteta $13.33-54.88 \mathrm{~cm}$, dominant thickness of mud at three values are $23.88 \mathrm{~cm}, 30 \mathrm{~cm}$, and $38.33 \mathrm{~cm}$ with a diversity of mud thickness 23 diversity (Figure 6). The location of the mangrove ecosystem of Beringin Beach has a thickness of mud $19.55-58.77 \mathrm{~cm}$ with a dominant value of mud thickness of $19.55 \mathrm{~cm}$, and six thickness of mud diversity (Figure 7). While the Pitai forest mangrove ecosystem shows the thickness of the mud is $26.55-37.88 \mathrm{~cm}$ with a diversity of 7 (Figure 8). In the four locations of this research, the Pariti mangrove ecosystem has the highest mud thickness where the thickness value is $17.33-79.11 \mathrm{~cm}$, with the dominant thickness value of $43.22 \mathrm{~cm}$ and the thickness of mud density 132. This is in line with the statement of Noor

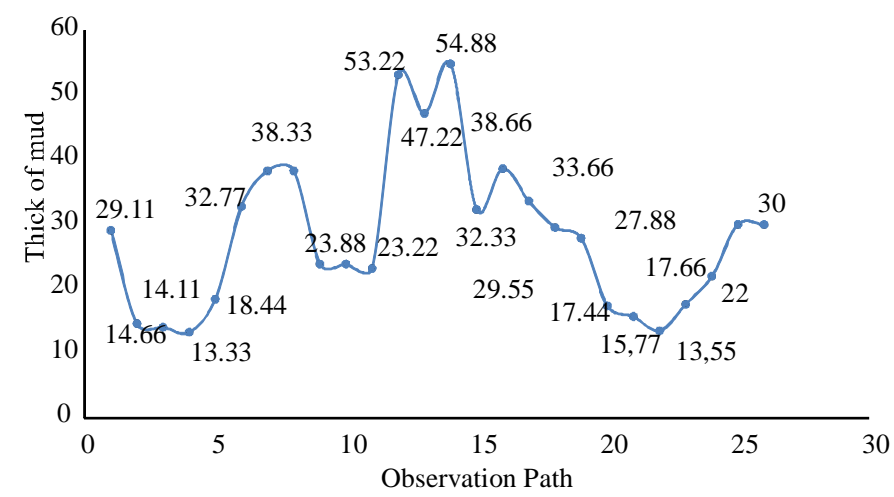

Figure 5 Mud thickness variation in different sampling lines of Oeteta mangrove location.

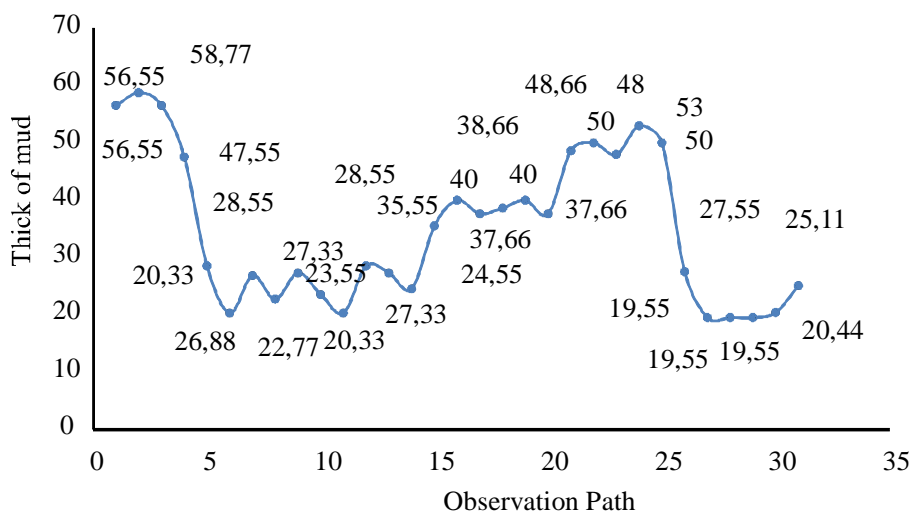

Figure 7 Mud thickness variation in different sampling lines of Pantai Beringin mangrove location. et al. (1999) that the condition of mud thickness greatly affects the ability to rooting mangrove vegetation in capturing sediment transported by water when the water tide occurs, where the thickness of the mud will affect the pharmaceutics vegetation, because tree roots are able to bind and stabilize mud. If we compare the thickness of the fourth mud research site with other locations in Indonesia such as in the area of coral Ganding Langkat northeast of North Sumatera that has a mud thickness of 59.07-131.95 cm (Siahaan, 2016), then the thickness of the mud is Sulamo Subdistrict shows more low value. This is due to the research area is very less large rivers flowing throughout the season, so this affects the thickness and characteristics of mud substrates. The condition of the rocky geography becomes an integral part of the coastal mangrove ecosystem of the Sulamo subdistrict, it is in line with the opinion (Majid, 2016), that the mangrove forest can grow on the Coral beach, where the coral reefs die on the top of which is a thin layer of sand or mud or muddy beaches. The condition of mud thickness on the beach coastal of Sulamo Subdistrict mangrove ecosystem is shown in Table 1, Table 2, Table 3, and Table 4.

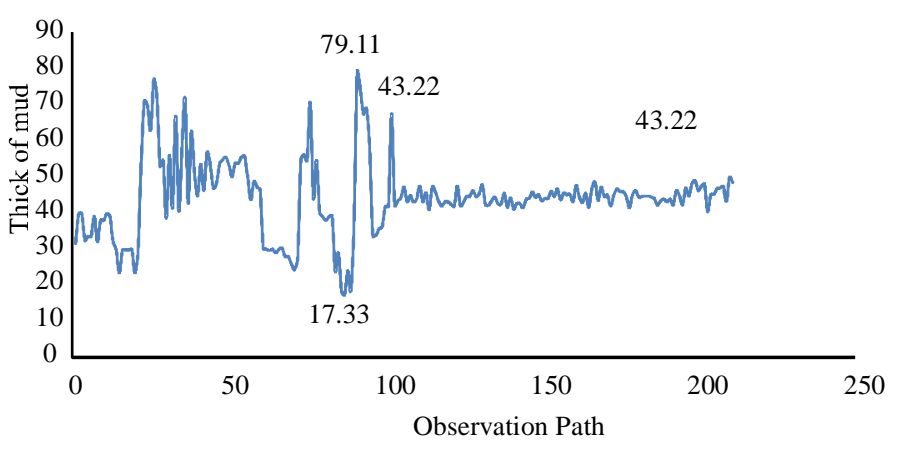

Figure 6 Mud thickness variation in different sampling lines of Pariti mangrove location.

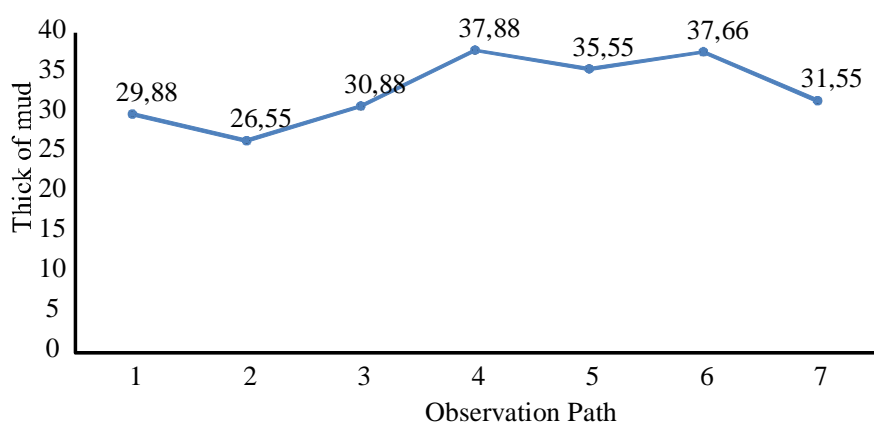

Figure 8 Mud thickness variation in different sampling lines of Pitai mangrove location. 
Condition of slope mangrove ecosystem The mangrove ecosystem provides an important function in living creatures. However, human beings with various activities give threats to the existence of mangrove ecosystem (Fusi et al., 2016) so that the mangrove ecosystem suffered damage and damage could be permanent even not only happens to the structure and density, but this damage also occurs in the existence of species (Astiani, 2016). Therefore, understanding the condition of mangrove ecosystems, such as the slope of the beach, becomes an important thing in various activities of rehabilitation planning or restoration that will be done against the mangrove ecosystem.

The beach slope in the Sulamo mangrove ecosystem shows a variation of slope of $14 \%$. The mangrove ecosystem of Oeteta showed a slope of 1-2\% (Figure 9), Pariti 14\% (Figure 10), Banyan Beach 13\% (Figure 11), and Pitai 23\% (Figure 12). These four locations have the dominant value of inclination at the value of $2 \%$, with varying grades of slope diversity in which Oeteta shows the value of diversity by five

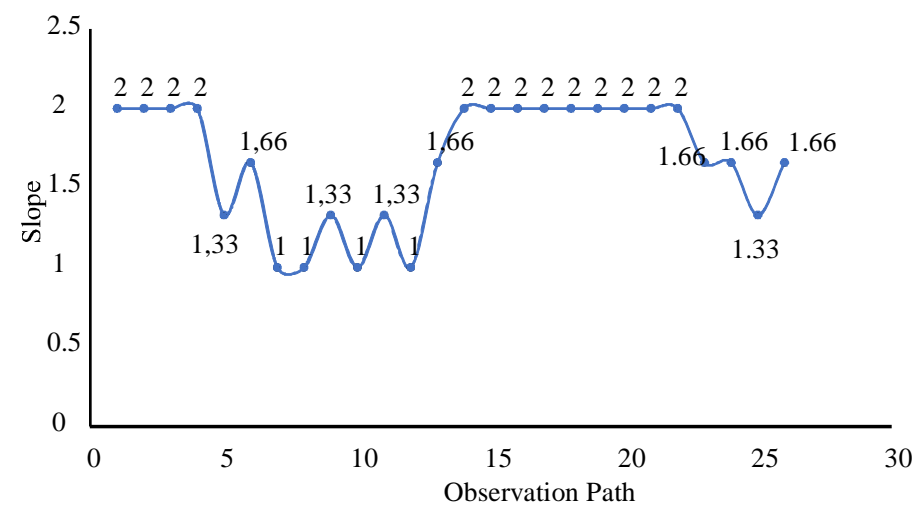

Figure 9 Costal slope variation in sampling lines of Oeteta mangrove location.

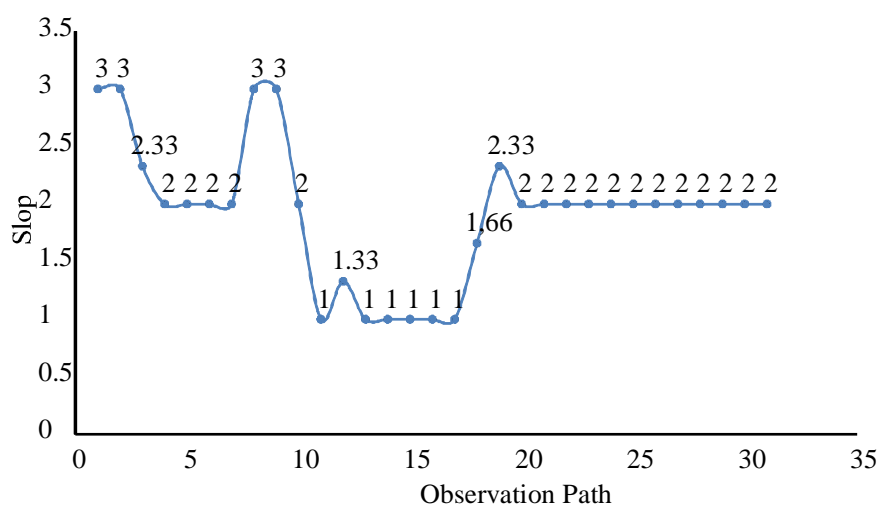

Figure 11 Costal slope variation in sampling lines of Pariti mangrove location. diversity, Pariti 8 diversity, Beringin Beach 6 diversity, and Pitai 7 diversity. The slope condition in the mangrove ecosystem indicates a high slope where the slope range can reach $4 \%$. This is very different from the slope of a mangrove forest ecosystem on the north coast of North Sumatra that has a slope carried $<2 \%$ ( Kusmana et al., 2018). Please note that the slope of the coastal mangrove ecosystem affects the growth of mangrove, this is due to slope and ups and downs are two interconnected, where the beach characteristics such as the Luasan, the length of the coastline is associated with winnings and sedimentation. The slope conditions of the mangrove ecosystem of the Sulamo Subdistrict are shown in Table 1, Table 2, Table 3, and Table 4. When environmental conditions such as salinity, mud, and slope of the coast support, it will be constructive in the process of generation, especially in the germination of seeds such as Avecennia marina type (Hastuti \& Budihastuti, 2016).

Dendrogram physicochemical Classification to place unity or similar objects into groups, or we commonly call clusters

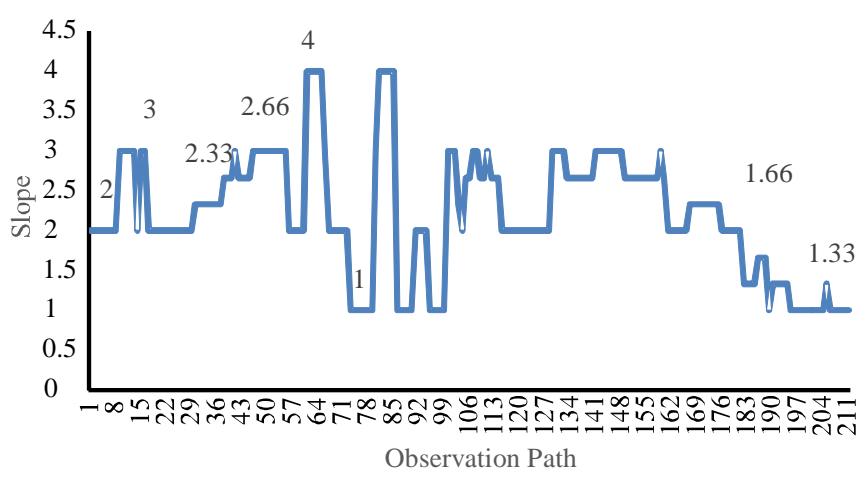

Figure 10 Costal slope variation in sampling lines of Pariti mangrove location.

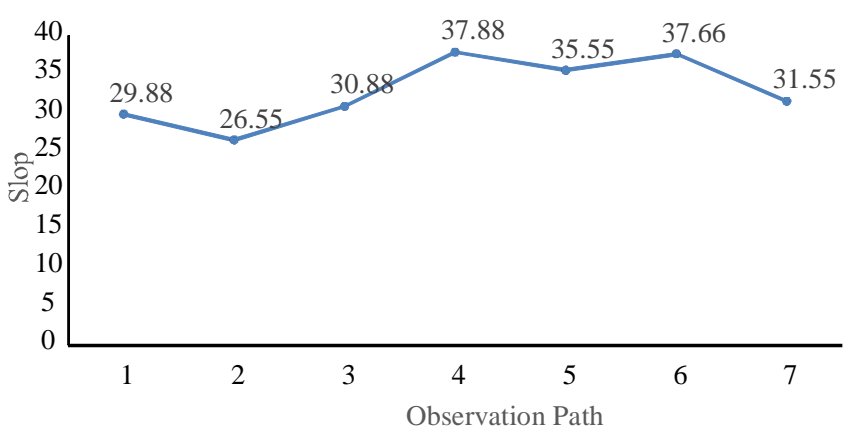

Figure 12 Costal slope variation in sampling lines of Pitai mangrove location. 
to be important things to know to ensure the similarity of a group with another group (Ludwig \& Reynold, 1988). The objectives of cluster analysts conducted in salinity conditions, mud thickness, and slope to group conditions of mangrove growth, which are located at four research locations so that the similarity with other locations can be found in one cluster. The results of the cluster analysis carried out to 3 environmental factors such as salinity, mud thickness, and slope indicate some proximity to four research locations. The dendrogram results of analysts showing three groupings of similarity to environmental conditions. The first group formed was the similarity of environmental conditions between the locations of Pariti and Pitai. The second group formed was the group between the locations of Oeteta-Pariti and the third group formed between the location of Banyan Beach with the location of Oeteta and Pariti. This grouping can be explained by the proximity of distances that occur in the field, but there are the most important things seen that the similarities that occur in the group are not forever because of the adjacent location. This can be seen in the location of Pariti and Pitai, forming a group of similarities, but the reality in the field of the second location has a long-distance even through some other mangrove forest expanse. Different from the second and third groups form the group because of the proximity distance or within one stretch of coastal adjacent to each other. The dendrogram grouping occurs due to the resemblance environmental condition of mangrove growth can be seen in Figure 16. The results of the proximity analysis environmental condition mangrove growth are very beneficial because it relates to various restoration and rehabilitation activities, such analysis will be constructive for the local government in conducting a variety of mangrove forest management plans located on the coastal District of Sulamo.

Spatial distribution of environmental conditions mangrove ecosystem Nowadays, developing countries have damaged mangrove forest due to various human activities (Meng et al., 2016). Spatial distribution of salinity conditions, thick mud, and slope in the mangrove ecosystem should be known to be the basis of the planning and management of coastal areas. According to (Manurung et al., 2017) that currently, the mangrove forest facing a variety of anthropogenic disorders, especially from knees of the mud with a density of $31-32 \mathrm{~cm}$ (slightly dark color), for thin mud conditions dominates the back. For the location of the mangrove ecosystem, Pitai is dominated by a somewhat industrial field, for it needs to be conducted environmental studies to get recommendations for the selection of types that match the condition of an existing environment. Map of spatial distribution the condition mangrove growth in Sulamo Subdistrict of Kupang District became much needed because, there has been a forest fragmentation that has impacted reduction in numbers and sizes (Zulfikhar et al., 2017).

The spatial distribution of salinity conditions shown on the interpolated map of field-scrolling data shows that the mangrove ecosystem with high salinity dominates the front up to the middle part of the Sulamo mangrove ecosystem with the highest salinity value of $32-43.33$ ppm (black color display on the map). While for salinity is dominating the front mangrove ecosystem and the central part with a salinity value of $30 \mathrm{ppm}$ (a slightly darker color display on the map) then followed with a low salinity that dominates the back of the mangrove ecosystem with a dominant value of $20 \mathrm{ppm}$ (a brighter light display). The map of salinity in the mangrove ecosystem of Sulamo Subdistrict can be seen in Figure 13. The spatial distribution of mud thickness based on the map shows that starting from the mangrove ecosystem of Oeteta adjacent to the Nunkurus River shows the thickness of thin with a value of $13.33 \mathrm{~cm}$ (light color) to a bit thick with the dominant value $38.33 \mathrm{~cm}$ (slightly darker color). Pariti mangrove ecosystem shows the thick spatial thickness of the mud in the middle with a value thickness can reach $54.88 \mathrm{~cm}$,

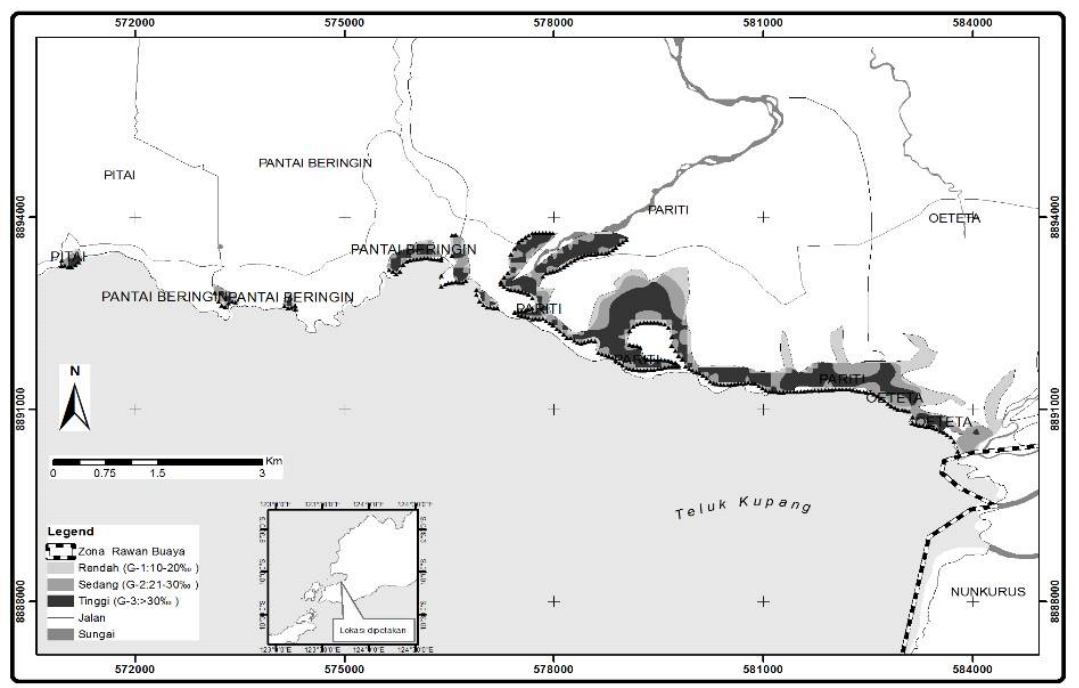

Figure 13 Map showing the distribution of salinity levels in the mangrove location of Sulamo Subdistrict, Kupang District, East Nusa Tenggara, Indonesia. 


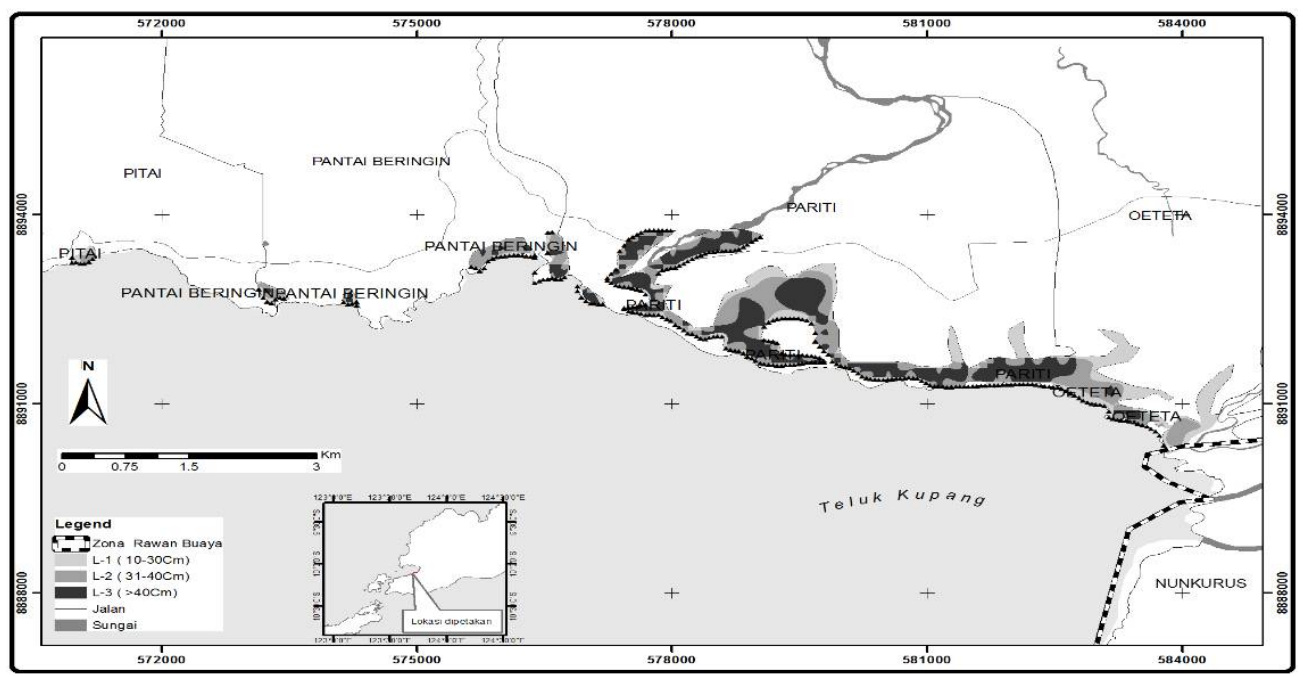

Figure 14 Map showing the distribution of mud thickness in the mangrove location of Sulamo Subdistrict, Kupang Distric, East Nusa Tenggara, Indonesia.

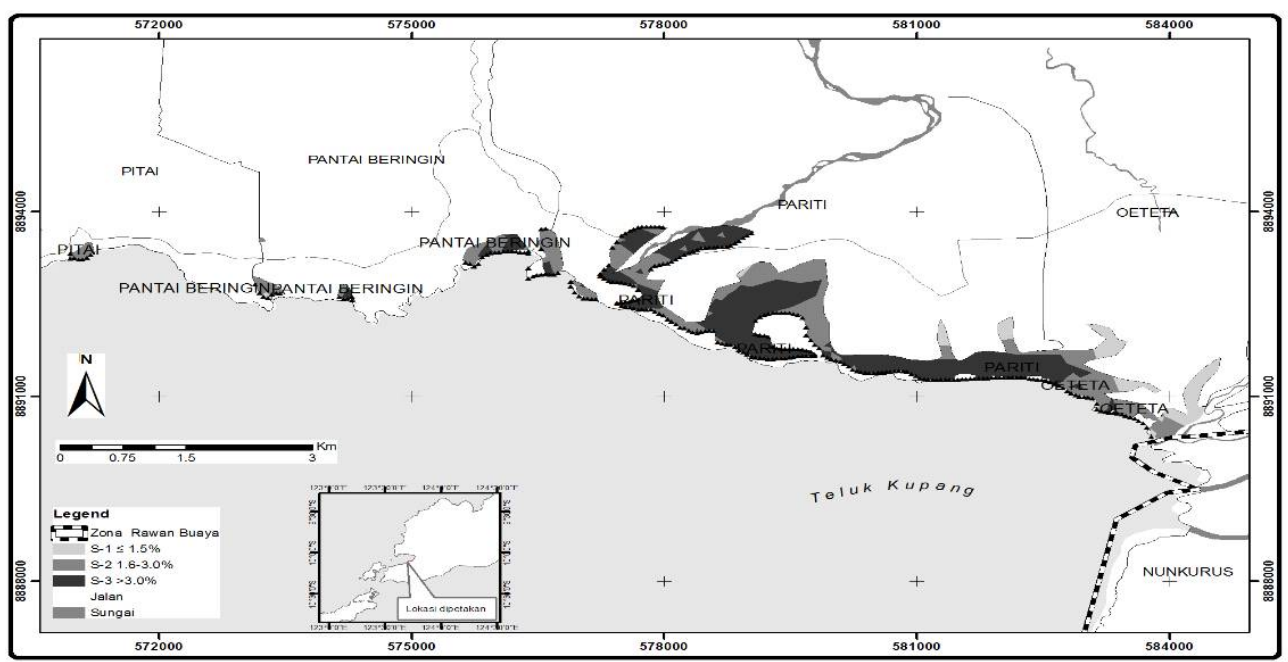

Figure 15 Map showing the distribution of slope in the mangrove location of Sulamo Subdistrict, Kupang District, East Nusa Tenggara, Indonesia.

while to a somewhat thick dominates the front, middle, and back with the value $34.33 \mathrm{~cm}$ while the mud dominates the back of the rear with a range of $19 \mathrm{~cm}$ values. The mud thickness of Beringin Beach is indicated by a spatial map of the front and center dominated by the mud thickness on the front, and the thickness of thin mud dominates on the back. Map of mud thickness of mangrove ecosystem Sulamo District can be seen in Figure 14. Slope of coastal mangrove ecosystem Sulamo District in dominance by a slope of $14 \%$ is seen in map spatial beach slope mangrove ecosystem that started from Oeteta with slope value dominated by $2 \%$ slope that in a spatial map drawn in a slightly dark color. For the Pariti area shows the black color that dominates most of the mangrove ecosystem area, while for the coastal area of Pantai Beringin has a value with variations from flat to ramps, this is different from the Pitai area which dominated by almost flat to ramps. The slope of the mangrove ecosystem of Sulamo Subdistrict can be seen in Figure 15.

\section{Conclusion}

The mangrove ecosystem located in Sulamo Subdistrict indicates salinity conditions, mud thickness, and slope varying in four research locations. The salinity conditions show a value of $19-42.33 \mathrm{ppm}$. The thickness of the mud shows the highest value at $79.11 \mathrm{~cm}$ and the beach slope $1-4 \%$. These results indicate the environmental conditions supporting mangrove ecosystem as well as expected the results of this research to be the basis for planning the management of the mangrove ecosystem in the coastal District of Sulamo. 


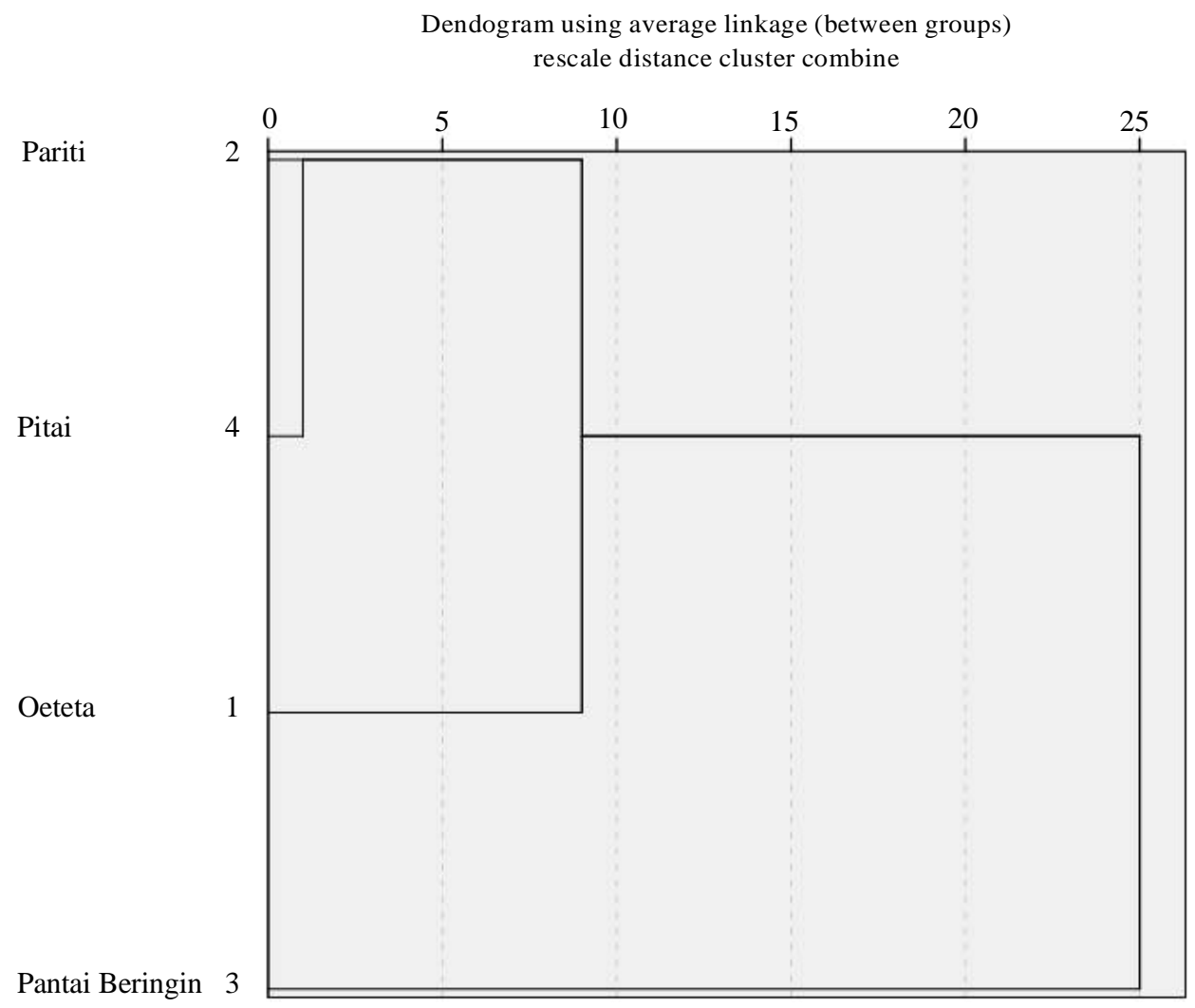

Figure 16 Dendrogram related to the assessed physicochemical parameters related to 4 mangrove locations.

\section{Recommendation}

It is necessary to do a further study of the community's conception of how the mangrove ecosystem for protection and community life in Sulamo District has been conducted.

\section{Acknowledgment}

We sincerely thank the Head of District of Kupang, head of the Sulamo Subdistrict and Natural Resource Conservation Hall, East Nusa Tenggara, which has permitted us to conduct research. We want to thank the mangrove group of Kupang Agricultural Polytechnic, which has been assisting in the implementation of this research.

\section{References}

Alonggi, D. M. (2002). Present state and future of the word's mangrove forests. Environmental Conservation 29(3), 331-349. https://doi.org/10.1017/S037689290200023

Anneboina, L. R., \& Kumar, K. S. K. (2012). Economic analysis of mangrove and marine fishery linkages in India. Ecosystem Service, 24, 114-123.

Astiani, D. (2016). Tropical peatland tree-species diversity altered by forest degradation. Biodiversitas, 17, 102-109. https://doi.org/10.13057/biodiv/d170115

Baran, E. (1999). Review of quantified relationships between mangrove and coastal resources. Phuket Marine
Biological Center Research Bulletin, 62, 57-64.

Basyuni, M., Gultom, K., Fitria, B. A., Susetya, I. E., Wati, R., Slamet, E., Balke, \& Bunting, P. (2018). Diversity and habitat characteristics of macrozoobenthos in the mangrove forest of Lubuk Kertang Village, North Sumatra, Indonesia. Biodiversitas, 19, 311-317. https://doi.org/10.13057/biodiv/d190142

Dahuri, R. (2003). Keanekaragaman hayati laut: Aset pembangunan berkelanjutan Indonesia. Jakarta: Gramedia Pustaka Utama.

Davinsy, R., Kustanti, A., \& Hilmanto, R. (2015). Study of mangrove forest management in the Pahawang Island Village Marga Punduh District Pesawaran Regency. Sylva Lestari, 3, 95-106.

Febryano, I. G., Suharjito, D., Darusman, D., Kusman, K., \& Hidayat, A. (2014). The roles and sustainability of local institutions of mangrove management in Pahawang Island. Jurnal Manajemen Hutan Tropika, 20, 69-76. https://doi.org/10.7226/jtfm.20.2.69.

Fusi, M., Bione, G. M., Suciu, N. A., Sacchi, A., Trevisan, M., Capri, E., ... Cannicci, S. (2016). Ecological status and sources of anthropogenic contaminants in mangroves of the wouri river estuary (Cameroon). Marine Polution Bulettin, 109(2), 723-733. https://doi.org/10.1016/ j.marpolbul.2016.06.104 
Husodo, T., Palabbi, S. D. G., Abdoellah, O. S., Nurzaman, M., Fitriani, N., \& Partasasmita, R. (2017). Short communication: Seagrass diversity and carbon sequestration: Case study on Pari Island, Jakarta Bay, Indonesia. Biodiversitas, 18(4), 1596-1601. https://doi.org/10.13057/biodiv/d180438

Hastuti, Y. P., Affandi, R., Safrina, M. D., \& Faturrohman, K. (2015). Optimum salinity for growth of mangrove crab Scylla serrata seed in recirculation systems. Akua Kultur Indonesia, 14, 50-57. https://doi.org/10.19027/jai.14.5057

Hastuti, E. D., \& Budihastuti, E. (2016). Potential of mangrove seedlings for utilization in the maintenance of environmrntel quality within silvofishery ponds. Biotropia, 23, 58-63. https://doi.org/10.11598/ btb.2016.23.1.606.

Kunarso, A., Tubagus, A. A., Syabana, Azwar, F., \& Bastoni. (2015). Mangrove rehabilitation using silvofishery system in Telang Protection Forest, South Sumatra: Opportunities and challenges. Paper presented at The International Conference of Indonesia Forestry Researchers III. Bogor, 21 -22 October 2015.

Kusmana, C., Hidayat, T., Istomo, \& Rusdiana, O. (2018). Growth performance of Bruguiera gymnorrhiza derived from cut-propagule seedling. Biodiversitas, 19, 208-214. https://doi.org/10.13057/biodiv/d190128

Lapolo, N., Utini, R., Wahyuni, D. K., \& Baderan. (2018). Diversity and density of crabs in degraded mangrove area at Tanjung Panjang Nature Reserve in Gorontalo, Indonesia. Biodiversitas, 19, 1154-1159. https://doi.org/ 10.13057/biodiv/d190128

Ludwig, J. A. \& Reynold, J. F. (1988). Statistical ecology. New York: John Wilery \& Sons.

Majid, I. (2016). Mangrove forest conservation in the beach coast of Ternate integrated city with school curriculum. Bioedukasi, 4(2), 488-496.

Manurung, J., Siregar, I. Z., Kusmana, C., \& Dwiyanti, F. G. (2017). Genetic variation of the mangrove species Avicennia marina in heavy metal polluted estuaries of Cilegon Industrial Area, Indonesia. Biodiversitas, 18, 1109-1115. https://doi.org/10.13057/biodiv/d180331

Matatula, J. (2010). The study of mangrove habitat quality based on at Kupang Gulf coastal area East Nusa Tenggara [thesis]. Yogyakarta: Universitas Gadjah Mada.

Matatula, J., Pathibang, M. R., \& Aryani, N. K. A. D. (2017). Kualitas habitat mangrove di Pantai Tanah Merah Kabupaten Kupang. Paper presented at Seminar Nasional 2 Laborantorium Riset Terpadu Undana. (pp. 2432). Kupang, Indonesia.

Matatula, J., Pathibang, M. R., Aryani, N. K. A. D., \& Ngaji, A. U. K. (2018). Mangrove forest habitat conditions in
Tanah Merah coastal beach East Nusa Tenggara. Paper presented at International Conference on Climate Change, Biodiversity, Food Security and Local Knowledge. Artha Wacana Christian University. Kupang, 3-4 September 2018.

Matatula, J., Poedjirahajoe, E., Pudyatmoko, S., \& Sadono, R. (2019). The spatial spread of mangrove forest environmental condition at Kupang seashore. Jurnal of Natural Resources and Environmental Management, 9, 467-482.https://doi.org/10.29244/jpls.92 467-482

Meng, X., Xa, P., Li, Z., \& Meng, D. (2016). Mangrove degradation and response to anthropogenic disturbance in the Maowei Sea (SW China) since 1926 AD: Mangrove-derived $\mathrm{OM}$ and pollen. Organic Geochemistry, 98, 166-175. https://doi.org/10.1016/ j.orggeochem.2016.06.001

Noor, Y.R., Khazali, M., \& Suryadiputra, I.N.N. (1999). Panduan Pengenalan Mangrove di Indonesia. PHKA/WA-IP, Bogor.

Poedjirahajoe, E. (2006). Klasifikasi lahan potensial untuk rehabilitasi mangrove di pantai utara Jawa Tengah (Rehabilitasi mangrove menggunakan jenis Rhizopora mucronata) [dissertation]. Yogyakarta: Universitas Gadjah Mada.

Poedjirahajoe, E., Widyorini, R., \& Mahayani, N. P. D. (2011). Kajian ekosistem mangrove hasil rehabilitasi pada berbagai tahun tanam untuk estimasi kandungan ekstrak tanin di pantai utara Jawa Tengah, Jurnal Ilmu Kehutanan, 5(2), 111.

Purnobasuki, H., \& Utami, E. S. W. (2016). Seed germination of Avicennia marina (Forsk.) vierh. by pericarp removal treatment. Biotropia, 23,74-83. https://doi.org/10. 11598/btb.2016.23.2.346

Retnowati, Y., Sembiring, L., Moeljopawiro, S., Djohan, T. S., \& Soetarto, E. S. (2017). Diversity of antibioticproducing actinomycetes in mangrove forest of Torosiaje, Gorontalo, Indonesia. Biodiversitas, 18, 1453-1461. https://doi.org/10.13057/biodiv/d180322

Saparinto, C. (2007). Pendayagunaan ekosistem mangrove. Semarang: Effhar Offset.

Senoaji, G., Hidayat, F., Kehutanan, J., Bengkulu, U., Raya, J. \& Limun, K. (2016). Peran ekosistem mangrove di pesisir Kota Bengkulu dalam mitigasi pemanasan global melalu penyimpanan karbon. Jurnal Manusia dan Lingkungan, 23, 327-333. https://doi.org/10.22146/ jml.18806

Schaduw, J. N. W. (2018). Distribusi kualitas perairan ekosistem mangrove pulau kecil Taman Nasional Bunaken. Majalah Geografi Indonesia, 32, 40-49. https://doi.org/10.22146/mgi.32204

Siahaan, H. D. M. (2016). Ecological mangrove habitat in 
encroachment area of palm oil plantation in wildlife preserve area of Karang Gading Langkat Timur Laut, Nort Sumatra [thesis]. Yogyakarta: Universitas Gadjah Mada.

Sulistyorini, I. S., Poedjirahajoe, E., Faida, L. R. W., \& Purwanto, R. H. (2018). Social capital in mangrove utilization for silvofishery: Case study in Kutai National Park, Indonesia. Jurnal Manajemen Hutan Tropika, 20, 60-69. https://doi.org/10.7226/jtfm.24.2.60
Wiryanto, Sunarto, \& Rahayu, S. M. (2017). Biodiversity of mangrove aquatic fauna in Purworejo, Central Java, Indonesia. Biodiversitas, 18, 1344-1352. https//doi.org/ 10.13057/biodiv/d1180309

Zulfikhar, Zulkiflih, H., Kadir, S., \& Iskandar, I. (2017). The landscape structure change of the tropical low forest and its possible effec on tree species diversity in South Sumatra, Indonesia. Biodiversitas, 18, 916-927. https://doi.org/10.13057/biodiv/d180308 